\title{
INCLUSIVE GROWTH
}

\section{AND ADMINISTRATIVE REFORM IN THE BRICS COUNTRIES}

\author{
Leonid Smorgunov \\ Dr., Ph.D., Professor, Chair of the Political \\ Governance Department, Faculty of Political Science, \\ St. Petersburg State University \\ Address: 7/9 Universitetskaya Embankment, \\ 199034 St. Petersburg, Russian Federation. \\ E-mail: 1.smorgunov@spbu.ru
}

\begin{abstract}
The paper concerns administrative reform in the BRICS countries as a requirement of inclusive economic growth. The relationship between economic growth and equity describes the concept of inclusive development. In this respect, justice and quality of life is becoming one of its key factors and a stimulating cause of long-term economic development. The concept of an equitable (inclusive) growth strategy is based on the premise of the unity of governability, competitiveness and public policy through citizen participation. An important association of governability, competitiveness and fairness is participatory institutions. Four of these are crucial: strategic policy institutions; institutions of decentralization; institutions of "open government", and accountability institutions. The paper, based on analysis of the BRICS, demonstrates that these not only create an environment for development, but are also tools for citizens' participation.
\end{abstract}

Keywords: inclusive growth; administrative reforms; political institutions; open government; BRICS countries.

Citation: Smorgunov, L.V. (2018). Inclusive Growth and Administrative Reform in the Brics Countries. Public Administration Issues, Special Issue (electronic edition), pp. 80-95 (in English); DOI: 10.17323/1999-5431-2018-0-5-80-95.

\section{Introduction}

The member countries of the international association called BRICS are currently tackling complex tasks of domestic and international development. Proclaimed by the declaration of the 9th BRICS Summit in Xiamen (2017), the call for a new world economic order based on inclusiveness and justice presupposes a number of steps that affect, among other things, the internal sphere of public 
administration. In this regard, it is rightly noted that "as the BRICS partnership aspires to become more influential in world affairs, the internal governance systems of its member states will be of fundamental importance in shaping their activities elsewhere, whether individually or collectively" (Tapscott et al, 2017, p. 2). At the same time, it is important to note that administrative reforms are not a strictly independent activity of the modern governments of the BRICS countries. They are built into the complex task of ensuring sustainable and equitable economic development in individual countries and in the world as a whole.

One of the most important factors in maintaining a certain stability or orientation of economic development on justice and poverty reduction is institutional transformation. This is connected not only with the formation of the market institutions, but also with the participatory institutional development of public policy and administration. Some researchers have expressed doubts about the significance of the administrative factor in economic growth: "effective government is desirable, but what is not so clear is whether it is an essential or even important antecedent of rapid economic growth" (Kurtz, Schrank, 2007, p. 541). However, this position is overcome by the studies of modern economic growth, combined with inclusive development. P. Cerny and his colleagues deploy the concept of the 'competition state' - whose priority is 'maintaining and promoting competitiveness in a world marketplace and multi-level political system' - to identify national convergence but with variations in the era of neoliberal globalization (cit. on: Neilson, Stubbs, 2016, p. 123). Inclusive Advanced Competition States are characterized by a mix in which counter-capital and counter-market regulation figure more prominently whereas the Asian Tigers or Newly Advanced Competition States (India, China) which are characterized by a hybrid mix of relatively high pro-capital regulation and relatively high counter-market regulation (Neilson, Stubbs, 2014, p. 133). In general it can be argued that the concept of equitable economic growth strategy is based on the premise of unity of public governability, competitiveness and equitability. As has been stated, "It would require a more general design of democracy, i.e. democratic regime not only for politics but also for the field of economy. None other than Simon Kuznets... that for the study of the economic growth of nations 'effective... economy'" (Kuznets, 1955, p. 28). Li Zhao demonstrates the role of social economy in inclusive development: "The outlining of the past and the present leads to a consideration of the social economy as an important way to achieve a balanced economy and an inclusive society, together with the public sector and private for-profit sector" (Zhao, 2013, p. 1085). This democratization and social economy means building institutions that ensure not only growth, but also well-being. In this regard, developing a science approach in terms of the differences between the extract and inclusive institutions corresponds to a common understanding of the new economic and social order: "economic growth and prosperity are associated with inclusive economic and political institutions" (Acemoglu, Robinson, 2012, p. 91).

The study of administrative reforms in individual BRICS countries in recent decades has attracted increasing attention from researchers. Of particular interest are the reforms in Brazil. Here researchers analyze general administra- 
tive changes (Bresser-Pereira, 2003; Pereira, Orellana, 2009; Nunberg, Pacheco, 2016), new forms of involving citizens in public policy (Souza, 2001; Rios et al, 2014; Graft, Verhulst, Young, 2016), transparency, accountability and fighting corruption (Filgueiras, 2015). Russian administrative reforms receive a general description (Barabashev, Straussman, 2007; Gaman-Golutvina, 2008; Goncharov, Shirikov, 2013; Barabashev, Klimenko, 2017), although recently there are works on certain components of administrative reform (Smorgunov, 2016). India falls under the field of view of researchers in connection with the e-government, services and local government (Mathur, 2005; Nayyar, 2006). China is the object of research in connection with active economic growth and administrative progress (Zheng, 2004, 2007; Zhao, 2013; Hameiri, Jones, 2016, Chan, 2016). To a lesser extent, administrative reforms in South Africa are being investigated (Fryer, 2016; Tapscott, 2017). As a rule, administrative reforms in these countries are analyzed under a broad historical background of administrative changes. An international research project on the assessment of sustainable governance in the BRICS countries is acknowledged (Azahaf, Schraad-Tischler, 2012). In 2016, Fudan, China hosted the first international symposium on public administration in the BRICS countries (Tapscott et al, 2017). At the same time, the general directions of administrative reforms and their links with contemporary problems of economic development are poorly analyzed in a comparative manner.

This paper aims to describe the problem regarding the choice of methods in achieving a combination of economic growth and social development through the formation of bodies which can mediate between the political and administrative institutions in the BRICS countries. It will focus on the following topics: (1) a new type of economic development and requirements for administrative reforms; (2) the general directions of administrative reforms in the BRICS countries; (3) recent political and administrative transformations in the BRICS countries.

\section{Inclusive growth: a new paradigm for development}

The list of issues relating to the development of the BRICS countries follow the theme of economic growth based on a combination of justice and quality of life. Although the theory of economic growth affirmed the incompatibility of efficiency and fairness, many researchers now say that, in itself, intensive economic growth without equity is not a measure of modern development. Yes, the pace of growth in the BRICS countries is ahead of the "old world", but they are still a long way from that system, which provides life satisfaction for the populations of these countries. At the same time, a simple assumption is accepted that the policy of economic growth in these countries is not linked to the issues of equity and quality of life. Although, of course, it is assumed that without economic growth these problems cannot be updated, but it is believed that it is difficult or even impossible to solve problems at the same time by the combination of growth and quality of life under the conditions of modern economic world competition. The relationship between economic growth and equity is described in the concept of inclusive development. As written by Michael Spence - the Nobel 
laureate in Economics: "Inclusion has become the most essential part of sustainable growth. Initially, the concept of "inclusiveness" comes to economic science from India, but now it is used very widely. It concerns the distributional aspects of growth and expresses two basic ideas: 1) opportunities, created by growth, should be open to people; 2) the degree of inequality of income and access to basic services should be limited to acceptable levels" (Spence, 2011, p. 116-117). The problem, therefore, rests on the synergy of public policy objectives and its ability to combine economic growth and performance of vital functions. We are talking about the state governability as a system built on the principles of a complex combination of tasks, rather than priority ranking. In this respect, equity and quality of life, as a long-term outcome of economic development, become its (governability) main factor, stimulating cause.

With regard to the BRICS countries, none of these factors are obvious. If the "Asian Tigers" have demonstrated economic growth as a whole by the market centralization and sustainable management of the project, the BRICS countries are demonstrating a different strategy. Almost all of them are trying to connect the problem of economic growth with a solution to problems of social exclusion, by trying to raise the level of social policy at the same time as the human capital for the development and quality of life. Brazil also shows a more intensive policy of equitable economic growth. In this respect, it is interesting to compare the Russian experience of the patrimonial state, where the balance of economic growth problems rests on the need to strengthen the justice and quality of life, with the experience of Brazil and China, demonstrating the different models of public policy governance, but with a reduction of poverty as social exclusion. Social-democratic policy over the last decade in Brazil demonstrates the success of the fight against poverty on the basis of equity and growth. Social policy in China is based on economic growth with a demonstration of the prestige of the new quality of life. India is trying to solve the problem of poverty through enormous investments in education and science.

Although there is the correct understanding that "a growing body of work in economic growth theory argues that the growth process is not universal" (Hanson, 2013, p. 241), we can talk about three main paradigms of economic growth. One of these is the model of "an investment-based growth". In an investmentbased growth paradigm, growth is driven by "implementation innovations" and consists of sustained, high levels of capital investment and the local adoption of technologies developed elsewhere. The second is the model of "an innovationbased growth". In an innovation-based growth paradigm, by contrast, growth consists of "leading-edge innovations" that develop new technologies and push the frontier outward (Aghion, Howitt, 2006). Now we could mention the new developing paradigm of economic growth and development. It's based on intensive use of human capital. As Hanson writes, "driving up rates of capital investment and sheltering firms from competition become increasingly inefficient as growth depends more on leading-edge innovation. Instead, growth is founded on high levels of human capital and inventive activity" (Hanson, 2013, p. 241). This third paradigm could be named as "a human-based growth". All aspects and forms of human capital development are not only well-being indicators, but also 
effective drivers of economic growth. This growth ensures inclusiveness, which is expressed in the formation of inclusive institutions and broad social inclusion. We could adopt the definition of social inclusion: it "has highlighted important concepts that are central to the notion of social inclusion such as equality, rights and social cohesion and draws attention to barriers or inequalities that prevent individuals or groups from taking a full role in society" (Warburton, Sik Hung, Shardlow, 2013, p. 4). In this respect, the growth paradigm, based on human capital development, can be considered as inclusive growth. Then "by inclusive growth, we mean that growth process which benefits all sections and all regions of the economy, though not in a uniform manner. In other words, the growth of a country would be considered to be inclusive growth if along with the increase in the GDP (Gross Domestic Product) of a country, the HDI (Human Development Index) also increases" (Roy, 2011, p. 47). Although the state has an important role in investment policy and the national innovation system, its role increases in respect of inclusive development. The role increases not in the sense that the state assumes the main function of redistribution of the fruits of economic growth. The state has an important role in building the institutions between economy and society, between economic and social development. And here we can talk about two important processes and structures related to public governance. The first is the governance of public policies. Secondly, is the introduction of new institutions for the implementation of political and administrative decisions. Together they "create institutional mechanisms that mediate between economic and social development" (Nayyar, 2006, p. 825).

\section{Public administration reforms in the BRICS countries: a general outline}

The BRICS countries, in the last three decades, in the course of administrative reforms, laid the foundations of a new public administration system, which as a whole has demonstrated its effectiveness by high rates of economic growth and more or less successful social achievements. Of course, there are the old and new diseases (corruption, nepotism, "manual control", disrespect for the law, and others.), but step by step with the introduction of new institutions and mechanisms, that are demanded by the real problems, the situation changes. There is a gradual process of learning what the content of good governance is. Since 1982, China's seven rounds of institutional reforms have led to the reorganization of the central governmental bodies, accompanied by a reduction in their number, increasing the strategic role of macro-control, and the formation of a new civil service system. In the course of these reforms, there is considerable decentralization of administration and the quality of relations between central and local government. Significant rights were delegated to governance in municipalities. The 18th Congress of the CPC in October-November 2012 set the targets of the new administrative reform, which included the construction of a public administration on the basis of law, improving the system of public services, separation of functions of administrative bodies from the state-owned enterprises management functions, state assets management authorities, and others (Kirillov, 2013; Troshchinskiy, 2014). However, it should be noted that the state in China 
was transformed under the influence of the market economy, while maintaining leading positions in the public administration system. As Yong Zeng writes, "globalization has weakened the power of the Chinese state in some areas, and the state has responded to its declining power consciously in some cases and unconsciously in others. The Chinese state has not merely played the role of the fire brigade, reacting passively to the negative consequences of economic transformation and globalization. Instead, the state has adopted a proactive approach to re-make the state system. These conscious actions has not only modernized the Chinese state but also strengthened the power of the state in many aspects" (Zheng, 2004, p. 2). The second administrative reform in India in 2005 (the first was held in 1966) contributed to the introduction of new public management, the development of e-government and e-services, crisis management, administrative ethics, a performance evaluation system at all levels of public administration, and others. In 1995, in Brazil the President, Fernando Cardoso, launched a policy plan of state apparatus reform, aimed at finding a way out of the fiscal crisis, the collapse of the public administration in the global economy and the inability of bureaucracy to deal with the provision of public services. The reorganization affected all levels of public administration, and came under the general ideological aspirations of social liberalism, which would ensure the protection of social and economic rights, creating a more competitive environment for the implementation of public services. In Russia, the administrative reform 2003-10 made significant structural, functional and motivational changes to the system, although it has not been implemented in accordance with the original plans. Augmented by further formation of e-government and e-services system as a whole, it has enabled a rise in the level of efficiency of public administration and its consistency with the objectives of economic stabilization and development. Since 1994, with the adoption of the Public Service Act, administrative reform has been ongoing in South Africa, aimed at enhancing the abilities of officials and the public administration system as a whole. This reform was carried out along the way, especially the rationalization of management, increasing the role of law and the coordination of central and local management systems. For example, in 1995, South Africa adopted a law on labor relations which was "aimed at economic development, social justice and the democratization of the workplace" (Schulz, 2015, p. 268). All these public-administrative transformations contributed to the stabilization of the public governance systems in the BRICS countries, their focus on efficiency and quality of public services, economic development and social rights. It should be noted that the impact of the reforms in the countries was different, as well as their social and economic effects. However, the overall handling was provided with regard to the solution of contextual tasks corresponding periods. In recent years, the BRICS countries have been faced with contemporary challenges and risks choosing new measures for the public administration and putting them on the current political agenda.

New challenges to the systems of public administration are determined by external and internal factors and conditions. Governability today requires sensitivity to the risks and terms of instability and uncertainty, generated by the new economic, social and political reality. A modern public administration system 
should not only meet the new challenges, but also promote innovations, encourage their, give priority to institutions that have become the need of sustainable and competitive development. Although there is a belief that the quality of public governance is not directly linked to economic growth and that it is associated more with certain contextual conditions but not the cause of it (Kurtz \& Schrank, 2007, pp. 538-539), many gradually come to the realization that efficient and innovative public administration is a very important institutional factor of equitable development. There are different conceptual approaches to the relations of political regime and economic growth (from optimistic to skeptical); yet the question of the new nature of the development takes a closer look at the role not only of the political regime, but also the public policy and administration. Will economic growth be accompanied by positive effects in principle, independent of the political regime? Could the modern modes of democracy and authoritarianism with the same success contribute can contribute to economic growth? Whether or not the economic growth is based on social factors (equity, poverty reduction, employment, education and so on) largely depends on the political economy of development, defining public policy and democratic governance as a system element of equitable development. Modern "inclusive development of competitive state" (as well as new competitive states such as China and India) is based on a mixed strategy with respect to economic growth and its mechanisms: on the one hand, there is the strategy of capital development and control of the market (Neilson, Stubbs, 2016, p. 133), on the other hand, the public investment policies and programs become a factor for growth and development. In this respect, economic development cannot be measured without a welfare state and without public production of services (Stiglitz et al., 2016). The following main challenges currently facing public administration may be noted.

\section{Political institutions for inclusive growth}

It is clear that the modern public administration cannot simply create external conditions for economic development (such as security) or to carry out a different range of regulations in the economy; it is faced with the need to stimulate this development and innovation, creating the appropriative institutions and practices. In this respect, the modern transformation of public administration in the BRICS countries are not only aimed at creating investment regimes, but also the formation of a comprehensive policy of equitable economic development, which would have linked structural, institutional, functional justice and efficiency.

Political strategy and administrative tactics. Public administration was faced with the problem of a combination of political strategy and administrative tactics. Their inconsistency is not just the mismatch that creates extra costs and inefficiencies, but it becomes a hindrance for dynamism and competitiveness. On the one hand, focus on the primacy of politics in relation to the administration is determined by the criticism of New Public Management, in which the cost-effectiveness of spending budget or estimation of public personnel doesn't 
put any dependency on the quality of public policy implementation. Political contexts and questions are left by the wayside, especially relations between public policy and citizens. On the other hand, the complexity and uncertainty of the conditions of state activity exacerbated the problem of choosing the right public strategy for inclusion, and subsequently its effective implementation. Integrity and conjugation of government functions, expressed in public policy, are opposed to a non-integrated approach to competing agencies. In addition, efficiency assessment of public administration may not be complete and consistent, if it does not include an assessment of participatory public policy-making. As Laurence Lynn and Robbie Robichau write, "the formation of structures of public policy leads to further structural refinements of the administrative system. Intuitively, the policy is primarily due to the construction and design (directly and through management agents) administrative capacities and the division of labor "(Linn, Robichau, 2013, p. 218-219). This problem is a combination of policies and administrative practices of the country and take into account their specific character and experience. In this respect, for example, in Russia the task to build a system of balanced decision-making based on the principles of the Federal Law "On the strategic planning in the Russian Federation" (adopted June 28, 2014), and the political debate on the new administrative reform directly declares the problem of transition from a manual to a programmed method. By this law the state system of strategic planning is defined as the sum of the following subsystems: "interrelated strategic planning documents describing the priorities of socio-economic development of the Russian Federation; elements of regulatory, scientific and methodical, information, financial and other support strategic planning processes; members of the state strategic planning, implementing and directing the practical activities in this area" (Normativnoe..., 2014). The recent decision on the formation of the Presidential Council on strategic development and priority projects (Ukaz..., 2016) is another step in the creation of organizational conditions for coordination between state authorities, local government bodies, and public associations, and scientific and other organizations in addressing issues of strategic development of the country.

Modern administrative transformations in China fall under the banner of the idea of "governance in accordance with the policy", or "governance in accordance with the party directives and documents". As Yijia Jing points: "The leadership of the CPC over bureaucracy denies the politics-administration dichotomy that is supported by Weberian bureaucracy" (Jing, 2017, p. 63). On the one hand, this demand was the result of a certain increase in independence of governance structures. However, in connection with the identified degradation under a new government system (localism, corruption), there was a need for greater coordination of public administration in the country. Many experts consider this requirement as a step towards re-centralization. On the other hand, if you do not consider the contextual reasons then demand for communication policy and governance is a response to the growing complexity of public policy objectives in the face of uncertainty. Improving the coordination of values is due not only to a single political line, but also the formation of joint knowledge in the implementation of a unified policy in different local environments. At the end of the 
1990s in China the agencies, planners and direct economic management were abolished and the number of ministries was reduced by $28 \%$. According to Shaun Breslin, China's central government has moved away from direct control over production and distribution, it has adopted the model of "regulatory state", leaving the possibility of a broad macroeconomic policy to other public and private actors (Breslin, 2013, p. 64, 72). What outside observers can consider as "clearly the central government and powerful unified management system", says another researcher, in fact, is a "fragmented and chaotic structure, over which the central government has little control". The result is no centralized power solutions, but "horizontal negotiations between the government ministries, agencies and stateowned enterprises, as well as vertical negotiations between different levels of government that are involved in the implementation of the [policy]" (Hameiri, Jones, 2016, p. 84). In general, the Chinese state today is a multi-layered form of governance. In these circumstances, the central political leadership is concerned about delegating authority to lower levels of governance, but at the same time maintaining the unity of the political line in the form of merging party and government. Xi Jinping said at the 19th National Congress of the Communist Party of China in October 2017: "More decision making power should be given to governments at and below the provincial level, and ways should be explored to merge Party and government bodies with similar functions at the provincial, prefectural, and county levels or for them to work together as one office while keeping separate identities" (Xi Jinping, 2017, p. 35). This line of policy and administration unity we can also see in the CPC personnel policy, as well as in the formation of different coordinating political structures, such as the "leading small group" of the Politburo.

Citizens participation in policy-making. Imperative to the administrative reforms of the last decade is a response to the challenge of expanding the actors of policy making to include in this process the citizens and their associations. Trust, openness and cooperation are the terms and conditions of building a modern public administration. All of the BRICS countries respond by forming conditions that would include new political and expert discussion platforms, such as councils, public chambers, forums, etc., as well as the formation of "open government" systems or "open data", extending the possibility of government-society cooperation. While in India, for example, the problem of the formation of an "open government" system as an institution of public administration is a discussion, but creation of a platform of "open government data" and the adoption of several laws on information create conditions for closer cooperation between the citizens and the state, having, of course, their differences and inconsistencies. In 2005, the Indian Congress passed a new law on the right to information. This law removed a number of restrictions on the right to information, which the Supreme Court of India found impeding the constitutional right of citizens to freedom of expression. The adopted law allows Indian citizens after a nominal payment and certain procedures to obtain information from the governmental structures of different levels. The law increases the level of transparency of the government and provides tools to protect citizens' rights and to fight against cor- 
ruption. The researchers emphasize that, of course, the implementation of this law, especially in rural areas, is prone to all sorts of obstacles and constraints, but its progressive role is not denied by anyone in the community (Schulz, 2015, p. 268). In China, the modern administrative transformation is carried out on the basis of the idea of "promoting plural governance" as opposed to principles such as social control and unitary. To a greater extent this applies to the assumption of public services on the part of civil associations rather than direct participation by them in public administration. The expansion of the NGO functional boundaries, recognized by law, is the condition of "plural governance". In Russia in 2011, the idea of "open government" was not only developed, but also considerable resources for its functioning were created. There are a number of problems and contradictions: the structure itself is not homogeneous "open government", it is often used for mobilization, rather than stimulation, the culture of cooperation was not formed, and there is a large proportion of distrust by citizens, public officials and politicians (Smorgunov, 2016). However, the positive effects are also evident in solving a number of social and economic issues at the regional and local levels. In 2004, in Brazil the portal of transparency was established by the Comptroller General of the Federation, which allowed citizens to obtain information on the expenditure of budgetary funds. In 2009, the law ordered these portals to be opened in the federal states and some cities. At present, the transparency portal is visited monthly by more than nine hundred thousand unique users (Graft, Verhulst, Young, 2016). In September 2011 a law was passed, which institutionalized the National Action Plan for the development of open government in the country, the Inter-Ministerial Committee on Open Government and the Executive Committee of the groups. It is coordinated by the General Controller of the federation. As a result, Brazil adopted several laws regulating access to information (2011), Freedom of Information (2012); the open data portal was also created (2012). However, there is a weak role of civil society in the movement for open government in Brazil.

Decentralization of policy processes. The public administration system is facing the challenges of self-government and creativity, which are an integral part of innovation and development. In this respect, the administrative transformations involve some decentralization, reduction of excessive regulation and the inclusion of the subsidiary arrangements. Although all these measures are related to the different areas of administrative improvements, on the whole they contribute to creating the conditions for self-governance in the broadest sense, including the conditions for business development, resource allocation, delegation of authority, and the development of local initiatives. The literature emphasizes that "decentralization can have a very positive effect on the development, because it improves government efficiency, sensitivity, accountability and the impact of the citizens'" (Earle, Scott, 2010, p. 27). In China in 2013 the priority of administrative reform was to reduce the administrative practice of examination and approval of the activity by the state authorities. In Russia, the problem of excessive administrative regulatory activity was the subject of administrative reform from 2003-10 and remains relevant today. At the 
same time the central area of improving governance is a reduction of excess government regulation; improving the quality of public services; improving the efficiency of public authorities; and increasing transparency. In the aspect of self-governance and subsidiarity an important aim is the improvement of regional and especially local authorities. In China, for example, decentralization has brought many changes in the center of the relationship with the regions. Although in the recent years in connection with the fight against corruption the trend is bucking, however, fiscal decentralization, which changed the way of the formation of local taxes and revenues, maintained a new direction in relations between central and local authorities. The new separate tax system, introduced in 1994, allowed for the local authorities to collect taxes, fees and spending at the expense of the various projects. The second element of decentralization was the formation of the special administrative regions based on the decentralization of provincial governance structures. All of these innovations have allowed local capitalism to develop and often lead to the delimitation of the territory into separate "fiefdoms", however, as noted by observers, fiscal decentralization has established a new character of relations between the center and local areas and established in China "federalism de facto" (Zheng, 2007, p. 31, 73, 115). Fiscal federalism established in China in the mid-1980s, made her the most decentralized country in the world, despite the formal unitary character of the state government. The political institutions, namely, the personnel evaluation system and the system of dual accountability made it mandatory for local officials to increase tax revenues, allowing them to focus resources in the local credit institutions (Ong, 2012, p. 456).

In Brazil in the 1990s and 2000s the "government based on participation" is an important area of the administrative reforms. It fills a vacuum of citizens' influence on policy, formed due to the weakness of the party system and the absence of parliamentary developed traditions (Wampler, 2012, p. 344). Here, there is the "participatory budgeting", where citizens are mobilized to participate in the discussion of municipal budgets, as well as to create a number of administrative councils in municipalities (conselhos) which are involved in education policy, health care, transport, etc. An important place in the political and administrative influence is filled by the civil society associations, whose activities in cooperation with the state are conceptually described by the concepts of "right to have rights" and "participatory public". In India, 73 and 74 amendments to the Constitution in 1992 led to the formation of local self-government as the constitutional system, which includes the traditional councils of villages (the Panchayat Raj) and the city government, which expanded their powers to address political issues of local importance. To increase the representation of women in the villages, in August 2009, the boards of the central government of India decided to reserve to the Board 50\% of the seats for the female population.

Rising Accountability and Anticorruption Policy. A deficiency in responsibility and accountability is often referred to in the new governance system. "State institutions that are accountable to their people will use their resources constructively rather than misspend or steal them" (Gaventa, McGee, 2013, p. 5). 
This is of particular importance in the fight against corruption in the designated countries. In the past two decades, Brazil has been taking a number of anticorruption measures that increase openness and accountability in the public administration system. Among them are the opening of public budgets, the increase in the role of special financial control bodies, the development of a system of public audit organizations, the involvement of civil society in the control of public finances and other measures (Puppim de Oliveira, 2017, p. 12). However, as some scholars stress, in Brazil public control of corruption was centered on bureaucratic-administrative innovations, with few changes in judicial control and non-state public control (Filgueiras, 2015, p. 120). In Russia there is a National Anti-Corruption Plan (2016-2017), introduced by the President of the Russian Federation in 2016. According to this plan we could see some reformations: anticorruption examination of legal norms; openness of public authorities; regulating the activities of public authorities (laws and standards); informing citizens about the activities of the authorities and on civil rights; perfection of the judicial system; the irrevocability of punishment for corruption; increase in the social status of civil servants; introducing ethical standards; and competitive forms of recruitment to the civil service. In India, the phenomenon of corruption is no less significant than in other BRICS countries. As the researchers emphasize, corruption here is based on the closure of the bureaucratic apparatus from society. Hence, the policy of openness is the key to greater accountability and reducing corruption. The Chinese anti-corruption policy of the last decade has acquired new conceptual and institutional outlines (see: Manion, 2016). There is an important conceptual shift from targeting tougher punishment for corruption to preventative work against corruptionrelated behavior. In this regard, strengthening the institution of party control, open budget expenditures and declarations become the center of anti-corruption policy in modern China.

The formation of a responsibility and accountability system, the different institutions of accountability (monitoring, for example), the introduction of ethical codes of conduct, and citizens controlling institutions based on the law and open government are the signs of this general development. An important role is played by relatively independent and responsible institutions for monitoring and control, such as the Accounts Chamber of the Russian Federation, the Brazilian Federation of Accounts Tribunal, the National Audit Office of China, the Institute of the Comptroller and Auditor General of India, and the AuditorGeneral of South Africa. The National Audit Institutions of these countries have the function of an independent external audit of the public sector, established by the constitution or parliament. These institutions are responsible for control over the spending of public resources by the government, which they carry out in cooperation with parliaments and other regulatory and supervisory structures. They are responsible to the parliament, government or head of the state. Compared with other state organizations of audit, the national audit institutions have strict constitutional guarantees of independence. Their impact on the quality of public administration has increased in terms of financial management reforms and decentralization of the system. 
Other control institutions are related to the participatory mechanism of accountability. The movement for Transparency and Accountability Initiatives stresses the different modes of such mechanism, including the Public Expenditure Tracking Surveys, citizen report cards, score cards, social audits and community monitoring, participatory budgeting, sector-specific budget monitoring and participatory audits (Carothers, Brechenmacher, 2014). Brazil was the first country which implemented participatory budgeting. In Brazil, at the moment, the most effective way of directly including the citizens in policy-making is not political parties, and not representative authorities, but participatory budgeting. There are numerous complex social problems - the legal inequality of the black population, the marginalized population of the 'favelas', exacerbating the problems of drug trafficking and crime, etc. To address these problems the main emphasis was placed on increasing social inclusiveness through a special institution of participatory budgeting at the level of municipalities. The cycle of participatory budgeting lasts one year, during which citizens, through public meetings and negotiations between themselves and the local government, decide how to spend money on new projects for urban infrastructure, for example, healthcare, schools, and public roads. Participatory budgeting combines two models of democracy - direct democracy at the level of district assemblies and representative democracy at the level of the Council of Delegates and the Council for Participatory Budgeting. In Russia, participatory budgeting is expressed in the "Open Government" project of the "Budget for Citizens". This project was implemented at the federal and regional levels in 2013. The main directions of the project in Russia were the openness of the federal and regional budgets, the adaptation of budget data to citizens' perceptions, and the formation of an education system on the budget problem. Every Russian region has an open budget, and 47 regions of the Russian Federation implement the practice of initiative budgeting. The openness of regional budgets and their ranking are monitored. In 2017, the Ministry of Finance has prepared a draft program for the development of initiative budgeting in Russia.

\section{Conclusion}

The formation of public administration which meets the challenges of equitable development and improvement of social welfare level requires not only participatory institutions, but also participatory culture. The formation of institutions simultaneously transforms the consciousness and activity of participants in public administration. There is a period of searching for new principles and approaches that can later be transformed into policy and administrative reform under a new name. In the BRICS countries, administrative transformations take the form of permanent changes in public administration. The main directions of the current changes concern the enhancement of the strategic role of government policy, the development of civic engagement, the use of open government and open data for public administration and policy, and increasing the level of accountability and responsibility of the public administration system. Of course, all these changes are aimed at making the economic and social policies of states more efficient and inclusive. 


\section{REFERENCES}

1. Acemoglu, D. \& Robinson, J. (2012). Why Nations Fail. The Origins of Power, Prosperity, and Poverty. London: Crown Business. 544 p.

2. Aghion, P. \& Howitt, P. (2006). Appropriate Growth Policy: A Unifying Framework. Journal of the European Economic Association, vol. 4, no 2-3, pp. 269-314.

3. Azahaf, N. \& Schraad-Tischler, D. (2012). Governance Capacities in the BRICS. Gutersloh, Bertelsmann Stiftung.

4. Barabashev, A. \& Straussman, J. (2007). Public Service Reform in Russia, 1991-2006. Public Administration Review, vol. 67, no 3, pp. 373-382 (DOI: 10.1111/j.1540-6210.2007.00721.x).

5. Barabashev, A. \& Klimenko, A. (2017). Russian Governance Change and Performance. Chinese Political Science Review, vol. 2, no 1, pp. 22-29 (DOI: 10.1007/s41111-017-0057-z).

6. Breslin, S. (2013). China and the Global Political Economy. Basingstoke: Palgrave Macmillan. $256 \mathrm{p}$.

7. Carothers, T. \& Brechenmacher, S. (2014). Accountability, Transparency, Participation, and Inclusion. A New Development Consensus? Washington, DC: Carnegie Endowment for International Peace. 247 p.

8. Chan, H.S. (2016). The Making of Chinese Civil Service Law: Ideas, Technicalities, and realities. American Review of Public Administration, vol. 46, no 4, pp. 379-398 (DOI: 10.1177/0275074016634877).

9. Earle, L. \& Scott, Z. (2010). Assessing the Evidence of the Impact of Governance on Development Outcomes and Poverty Reduction. GSDRC Issues Paper. $52 \mathrm{p}$.

10. Filgueiras, F. (2015). Transparency and Corruption Control in Brazil. European Cooperation, vol. 1, no 1, pp. 115-128.

11. Fryer, D. (2016). State of the Art' or Dismal Science? The Economic Debate in South Africa since 1994. Arts \& Humanities in Higher Education, vol. 15, no 1, pp. 122-139.

12. Gaman-Golutvina, O.V. (2008). The Changing Role of the State and State Bureaucracy in the Context of Public Administration Reforms: Russian and Foreign Experience. Journal of Communist Studies and Transition Politics, vol. 24, no 1, pp. 37-53 (DOI: 10.1080/13523270701840449).

13. Gaventa, J. \& McGee, R. (2013). The Impact of Transparency and Accountability Initiatives. Development Policy Review, vol. 31, no 1, pp. 3-28.

14. Graft, A., Verhulst, St. \& Young, A. (2016). Brazil's Open Budget Transparency Portal. Making Public How Public Money is Spent. Available at: http://odimpact.org/static/files/casestudy-brazil.pdf (accessed: 12 July, 2016).

15. Goncharov, D. \& Shirikov, A. (2013). Public Administration in Russia. In: Public Administration in Post-Communist Countries. Former Soviet Union, Central and Eastern Europe, and Mongolia. Ed. by Liebert S., Condrey S., Goncharov D., pp. 23-42. Boca Raton, London, New York: CRC Press.

16. Hameiri, S. \& Jones, L. (2016). Rising Powers and State Transformation: The Case of China. European Journal of International Relations, vol. 22, no 1, pp. 72-98.

17. Hanson, J. (2013). Growth Paradigms and Congruent Institutions: Estimating Context-Varying Effects of Political Institutions on Economic Performance. Political Science Research and Methods, vol. 1, no 2, pp. 239-262. 
18. Jing, Y. (2017). Creative Incrementalism: Governance Reforms in China Since 1978. Chinese Political Science Review, vol. 2, no 1, pp. 56-68 (DOI: 10.1007/sw41111-017-0054-2).

19. Kirillov, A. (2013). Kitaj: vremja peremen [China: Time for change]. Ezhemesjachnyj zhurnal Kitay, no 12, pp. 22-25.

20. Kurtz, M. \& Schrank, A. (2007). Growth and Governance: Models, Measures, and Mechanisms. The Journal of Politics, vol. 69, no 2, pp. 538-554.

21. Kuznets, S. (1955). Economic Growth and Income Inequality. American Economic Review, vol. 45 , no 1, pp. 1-28.

22. Lynn, L. Jr. \& Robichau, R.W. (2013). Governance and Organisational Effectiveness: Towards a Theory of Government Performance. Journal of Public Policy, vol. 33, no 2, pp. 201-228.

23. Manion, M. (2016). Taking China's Anticorruption Campaign Seriously. Economic and Political Studies, vol. 4, no 1, pp. 3-18 (DOI: 10.1080/20954816.2016.1152094)

24. Mathur, B.P. (2005). Governance Reform for Vision India. New Delhi: Macmillan.

25. Nunberg, B. \& Pacheco, R.S. (2016). Public Management Incongruity in 21st Century Brazil. In: New Order and Progress: Development and Democracy in Brazil. Ed. by B.R. Schneider, pp. 134-161. Oxford: Oxford University Press.

26. Nayyar, D. (2006). India's Unfinished Journey Transforming Growth into Development. Modern Asian Studies, vol. 40, no 3, pp. 797-832.

27. Neilson, D. \& Stubbs, Th. (2016). Competition States in the Neoliberal Era: Towards ThirdGeneration Regulation Theory. Competition \& Change, vol. 20, no 2, pp. 122-144.

28. Ong, L. (2012). Fiscal Federalism and Soft Budget Constraints: The Case of China. International Political Science Review, vol. 33, no 4, pp. 455-464.

29. Pereira, C. \& Orellana, S. (2009). Hybrid Political Institutions and Governability: The Budgetary Process in Brazil. Journal of Politics in Latin America, no 3, pp. 57-79.

30. Puppim de Oliveira, J. (2017). Brazilian Public Administration: Shaping and Being Shaped by Governance and Development. Chinese Political Science Review, vol. 2, no 1, pp. 7-21 (DOI: 10.1007/s41111-017-0052-4).

31. Rios, A-M., Bastida, F. \& Benito. B. (2014). Budget Transparency and Legislative Budgetary Oversight: An International Approach. American Review of Public Administration, vol. 46, no 5, pp. 546-568.

32. Roy, A. (2011). Inclusive Growth through MFIs' Outreach in Assam. Asia-Pacific Business Review, vol. 7, no 3, pp. 47-62.

33. Schulz, M.S. (2015). Inequality, Development, and the Rising Democracies of the Global South. Current Sociology Monograph, vol. 63, no 2, pp. 261-279.

34. Smorgunov, L. (2016). Russian Movement for 'Open Government': Issues of Civic Engagement in Politics. International Journal of Electronic Governance, vol. 8, no. 3, pp. 211-228 (DOI: 10.1504/IJEG.2016.10002283).

35. Souza, C. (2001). Participatory Budgeting in Brazilian Cities: Limits and Possibilities in Building Democratic Institutions. Environment \& Urbanization, vol. 13, no 1, pp. 159-165.

36. Spence, M. (2011). The Next Convergence. The Future of Economic Growth in a Multispeed World. New York: Farrar, Straus and Giroux Publishing. 320 p.

37. Stiglitz, J., Sen, A. \& Fitoussi, J-P. (2016). Neverno otsenivaya nashu zhizn'. Pochemu VVP ne imeet smysla? Doklad Komissii po izmereniyu effektivnosti ekonomiki i sotsial'nogo progressa [Mis-measuring Our Lives. Why GDP Doesn't Add Upp. The report by the Commission on 
the Measurement of Economic Performance and Social Progress]. Per. s angl. I. Kushnarevoj. Moscow: Izd-vo Instituta Gajdara.

38. Tapscott, Ch. (2017). South Africa in the Twenty-First Century: Governance Challenges in the Struggle for Social Equity and Economic Growth. Chinese Political Science Review, vol. 2, no 1, pp. 69-84 (DOI: 10.1007/s41111-017-0055-1).

39. Tapscott, C., Puppim de Olivera, J., Jing, Y., Barabashev, A. \& Mathur, N. (2017). Introduction: BRICS in Search of Governance Models. Chinese Political Science Review, vol. 2, no 1, pp. 1-6 (DOI: 10.1007/s41111-017-0051-5).

40. Troshchinskiy P.V. (2014) Administrativnaya reforma v KNR: politiko-pravovye aspekty [Administrative Reform in the CPR: Political and Legal Aspects]. Administrativnoe i munitsipal'noe pravo, no 12, pp. 1264-1270 (DOI: 10.7256/1999-2807.2014.12.12735).

41. Wampler, B. (2012). Entering the State: Civil Society Activism and Participatory Governance in Brazil. Political Studies, vol. 60, no 2, pp. 341-362.

42. Warburton, J., Sik Hung, N.G. \& Shardlow, St. (2013). Social Inclusion in an Ageing World: Introduction to the Special Issue. Ageing and Society, vol. 33, no 1, pp. 1-15.

43. Xi Jinping (2017). Secure a Decisive Victory in Building a Moderately Prosperous Society in All Respects and Strive for the Great Success of Socialism with Chinese Characteristics for a New Era. Report Delivered at the 19th National Congress of the Communist Party of China October 18, 2017. Available at: http://www.xinhuanet.com/english/download/Xi_Jinping's_ report_at_19th_CPC_National_Congress.pdf (accessed: 24 December 2017).

44. Zhao, L. (2013). Conceptualizing the Social Economy in China. Modern Asian Studies, vol. 47, no 3, pp. 1083-1123.

45. Zheng, Y. (2004). Globalization and State Transformation in China. Cambridge: Cambridge University Press. 288 p.

46. Zheng, Y. (2007). De Facto Federalism in China: Reforms and Dynamics of Central-Local Relations. Singapore: World Scientific. 460 p.

\section{DOCUMENTS}

1. Normativnoe regulirovanie gosudarstvennogo strategicheskogo planirovanija. Available at: http://economy.gov.ru/minec/activity/sections/strategicPlanning/regulation/ (accessed 15 July 2016).

2. Ukaz Prezidenta Rossyskoy Federatsii N 306 ot 30 iyunya 2016 g. «O Sovete pri Prezidente Rossiyskoy Federatsii po strategicheskomu razvitiyu i prioritetnym proektam» (2016) [The decree of the President of the Russian Federation N 306, 30 June, 2016 "On the Soviet under the President of the Russian Federation on strategic development and priority projects]. Available at: http://www.kremlin.ru/events/president/news/52297 (accessed: 2 September, 2016). 